\title{
PREVENTIVE EFFECT OF N-STEAROYLETHANOLAMINE ON MEMORY DISORDERS, BLOOD AND BRAIN BIOCHEMICAL PARAMETERS IN RATS WITH EXPERIMENTAL SCOPOLAMINE-INDUCED COGNITIVE IMPAIRMENT
}

\author{
T. M. HORID'KO', H. V. KOSIAKOVA', A. G. BERDYSHEV', \\ O. F. MEGED ${ }^{1}$, O. V. ONOPCHENKO ${ }^{1}$, V. M. KLIMASHEVSKY \\ O. S. TKACHENKO ${ }^{1}$, V. R. BAZYLIANSKA 1 , V. O. KHOLIN ${ }^{2}$, \\ K. O. PESCHANA ${ }^{2}$, S. A. MYKHALSKIY' ${ }^{2}$ N. M. HULA ${ }^{1}$ \\ ${ }^{1}$ Palladin Institute of Biochemistry, National Academy of Sciences of Ukraine, Kyiv; \\ ${ }^{2}$ Institute of Gerontology, National Academy of Medical Sciences of Ukraine, Kyiv; \\ e-mail:TanGoRi@ukr.net
}

The impairment of cognitive functions is the most studied medical and social problem nowadays. The aim of this study was to evaluate the protective effects of N-stearoylethanolamine (NSE) on memory state, blood and brain biochemical parameters in rats under scopolamine-induced cognitive impairment. The results of this study shown that NSE administration to rats per os $(5 \mathrm{mg} / \mathrm{kg}$, 5 days, during last 3 days NSE was administrated $20 \mathrm{~min}$ prior to scopolamine injection (1 $\mathrm{mg} / \mathrm{kg}$, once daily for 3 days, intraperitoneally)) prevented the development of memory impairment. In particular, NSE action was associated with the prevention of increase in acetylcholinesterase activity, changes in phospholipid, free and esterified cholesterol level in hippocampus and frontal cortex, and disruption in pro-/antioxidant balance in blood and studied brain sections. Considering the above mentioned biological effects, NSE is a promising drug candidate for integrative therapy of cognitive impairment of different profiles.

Keywords: $N$-stearoylethanolamine, phospholipids, cholesterol, superoxide dismutase, catalase, glutathione peroxidase, nitrotyrosine, TBARS, acetylcholinesterase, scopolamine.

I $\mathrm{t}$ is known that the endocannabinoid system plays an important role in the regulation of memory, learning processes and emotional behaviour [1]. Inhibition of endocannabinoid hydrolysis contributes to the protection of blood-brain barrier integrity and prevents the development of neurological and behavioral disorders in rats [2]. Previous studies with fatty acid amidohyrodrolase (FAAH) inhibitors showed the increase of memory capacity and learning ability, contributing to the formation of a memorable trace via activation of PPAR $\alpha$ and CB1 receptors [3]. It was found that saturated $\mathrm{N}$-acylethanolamines (NAEs) modulate the activity and expression of FAAH [4], and as a high affinity ligands of PPAR $\alpha$ receptor [5], take part in memory formation processes. The results of previous studies in mice revealed the protective effect of N-stearoylethanolamine (NSE) on brain function, followed by the improvement of memory capacity in animals treated with lipopolysaccharide or immunized with the extracellular domain of the $\alpha 7$ nicotinic acetylcholine receptor [6]. In addition, NSE exhibited cannabimimetic activity [7], however, this effect was not mediated by the activation of $\mathrm{CB}$ receptors. It has been shown by earlier studies that NSE may prevent pathological changes in tissues via different biochemical mechanisms under multiple pathologics conditions [6]. Therefore, considering the already known biological effects of NSE, it was interesting to study its effects on memory state, blood and brain biochemical parameters in rats with experimental scopolamine-induced cognitive impairment.

(C) 2018 Horid'ko T. M.et al. This is an open-access article distributed under the terms of the Creative Commons Attribution License, which permits unrestricted use, distribution, and reproduction in any medium, provided the original author and source are credited. 


\section{Materials and Methods}

The study was conducted on 24 - month-old Sprague-Dawley outbred rats weighing between 350-400 g. These animals are considered aged. Rats were housed in standard cages with free access to food and water. All animal procedures were conducted in accordance with the requirements of the European Convention for the Protection of Vertebrate Animals used for experimental and other scientific purposes (Strasbourg, 1986).

To simulate cognitive pathology in animals we used scopolamine, a muscarinic antagonist which exhibits m-cholinoreceptor blocking activity and is employed as the gold standard for inducing memory impairments in experimental models [8].

Animals were devided into three experimental groups with 7 rats in each: "Control", "Scopolamine" - rats were injected intraperitoneally with scopolamine (1 $\mathrm{mg} / \mathrm{kg}$, once daily for 3 days) to simulate cholinergic deficiency, "NSE + Scopolamine" - rats were orally received the water suspension of NSE ( $5 \mathrm{mg} / \mathrm{kg}, 5$ days: during last 3 days NSE was administrated 20 min prior to scopolamine injection, per os) and were injected intraperitoneally with scopolamine (1 mg/kg, once daily for 3 days).

The effect of NSE on memoty of rats was studied using the passive avoidance reflex (PAR) test. The percentage of animals in the group with preserved passive avoidance reflex was evaluated in this test. PAR was trained, using a common technique of experimental light-dark chamber with an aperture, 15 min after the last administration of scopolamine $[9,10]$. PAR retention was checked after $24 \mathrm{~h}$. Rats that did not enter the dark chamber for 3 min were considered to pass the learning criteria. After 60 min of testing, animals were euthanized under $\mathrm{CO}_{2}$ anesthesia. Whole blood samples and separated brain structures were collected for biochemical studies.

The lipid extraction by Bligh and Dyer method [11] was performed to estimate lipid composition of hippocampus and frontal cortex. After that lipid extracts were separated by thin-layer chromatography, using solvent systems for the first dimention chloroform (65): methanol (30): ammonia (6): benzene (10), and the second dimention chloroform (5): methanol (1): acetic acid (1): water (0.5): acetone (2) [12]. The level of individual phospholipids was determined by Vaskovskiy and Kostetskiy method [13].

The intensity of the lipid peroxidation processes was carried out by the thiobarbituric acid reac- tive substances (TBARS) assay [14], superoxide dismutase activity (SOD, EC 1.15.1.1) was determined by the level of nitro blue tetrazolium reduction in the presence of NADH and phenazine methosulfate [15], catalase activity (CAT, EC 1.11.1.6) - by the level of hydrogen peroxide degradation [16], glutathione peroxidase activity (GP, EC 1.11.1.9) - by the accumulation of oxidized glutathione in the incubation environment [17]. The concentration of total protein was measured by Bradford method [18]. Superoxide dismutase 1 (SOD1) and nitrotyrosine levels were measured with a commercial rat enzyme immunoassay kits (cat No CSB-EL022397RA, Cusabio biotech co., cat No ab113848, Abcam, UK, respectively) in hippocampus and frontal cortex homogenates. Plasma acetylcholinesterase activity was determined using commercially available multienzyme kit (cat No MAK 119-1KT, Sigma, USA).

The data, presented as mean values \pm standard errors of the means (SEM), were compared using the Student's unpaired $t$-test. The differences were considered significant at $P<0.05$.

\section{Results and Discussion}

Behavioral studies. Animals that received scopolamine, compared to the controls, showed a significant memory loss (only 15\% of animals in the group within $24 \mathrm{~h}$ had a PAR retention) (Fig. 1).

Pretreatment with NSE prevented memory impairment in rats under scopolamine action (Fig. 1). Hence, $43 \%$ of rats from "NSE + Scopolamine" group showed PAR retention after $24 \mathrm{~h}$.

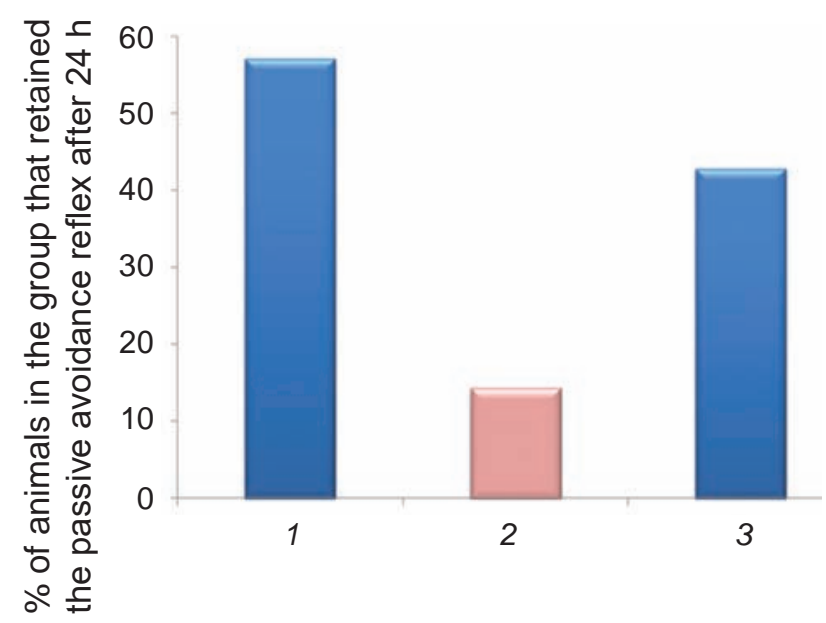

Fig. 1. Effect of $N$-stearoylethanolamine on the memory of rats: 1 - Control; 2 - Scopolamine; 3 NSE + Scopolamine 


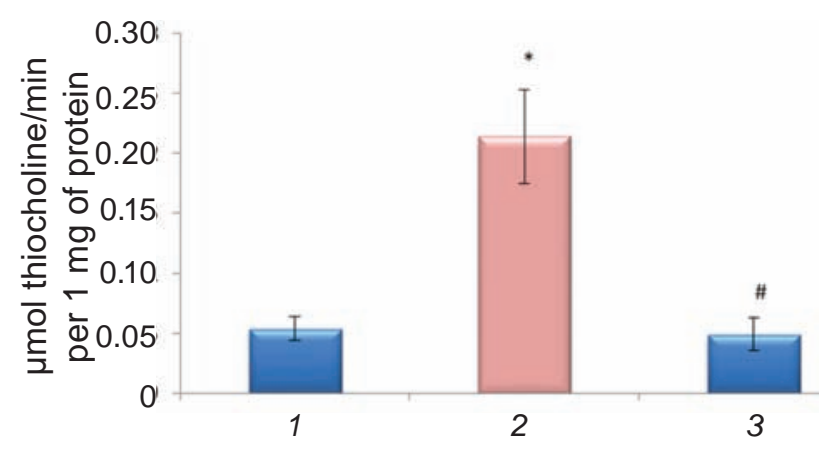

Fig. 2. Plasma AChE activity in control rats and rats with experimental cognitive impairment: 1 Control; 2 - Scopolamine; 3 - NSE + Scopolamine; values represent the mean $\pm \operatorname{SEM}(n=7) ; * P<0.05$ versus control rats; \# $P<0.05$ versus scopolamine rats

This data suggested that NSE prevents rats memory impairment under scopolamine action.

Biochemical studies. Acetylcholinesterase activity in plasma. Activity of acetylcholinesterase (AChE) increased in plasma of rats with experimental cholinergic deficiency induced by scopolamine (Fig. 2). Meanwhile, pretreatment with NSE prevented the increase of plasma AChE activity under the scopolamine action.

$S O D$ and nitrotyrosine protein level and SOD activity in the frontal cortex. The results of our study, presented in Fig. 3 and 4, showed that the SOD level and activity were significantly increased in the frontal cortex of aged rats with scopolamine induced cognitive impairment. However, scopolamine did not induce any significant changes in the content or activity of SOD in hyppocampus (data are not presented). In addition, obtained results suggest that scopolamine administration to rats triggered a decrease of nitrotyrosine level in the frontal cortex (Fig. 4).

Pretreatment of animals with NSE did not prevent the effect of scopolamine on SOD and nitrotirosin level, however, prevented the increase of SOD activity in the frontal cortex (Fig. 3, 4).

TBARS level and SOD, KAT, GP activity in plasma. Obtained data showed enhanced accumulation of TBARS in plasma of rats under scopolamine administration (Fig. 5, A). Also, we have found that activity of all studied antioxidant enzymes (SOD, CAT, GP) was significantly reduced in plasma of aged rats under the influence of scopolamine (Fig. 5, $B, C, D$ ). Pretreatment of experimental animals with NSE prevented a decrease in SOD, CAT, GP plasma activity (Fig. 5, $B, C, D$ ) and inhibited formation of TBARS (Fig. 5, $A$ ).

Total level of phospholipids and level of individual phospholipids in the frontal cortex and hippocampus.

Table represents the level of inorganic phosphorus of total phospholipids in the hippocampus and frontal cortex of rats with experimental cholinergic deficiency.

According to the obtained results (Table), scopolamine administration did not cause significant changes in the content of inorganic phosphorus of total phospholipids in the frontal cortex. In addition, NSE administration also did not affect the level of inorganic phosphorus of total phospholipids.

However, we have found a significant decrease in the content of inorganic phosphorus of total phospholipids in hippocampus of "Scopolamine" group (Table). Pretratment of experimental animals with
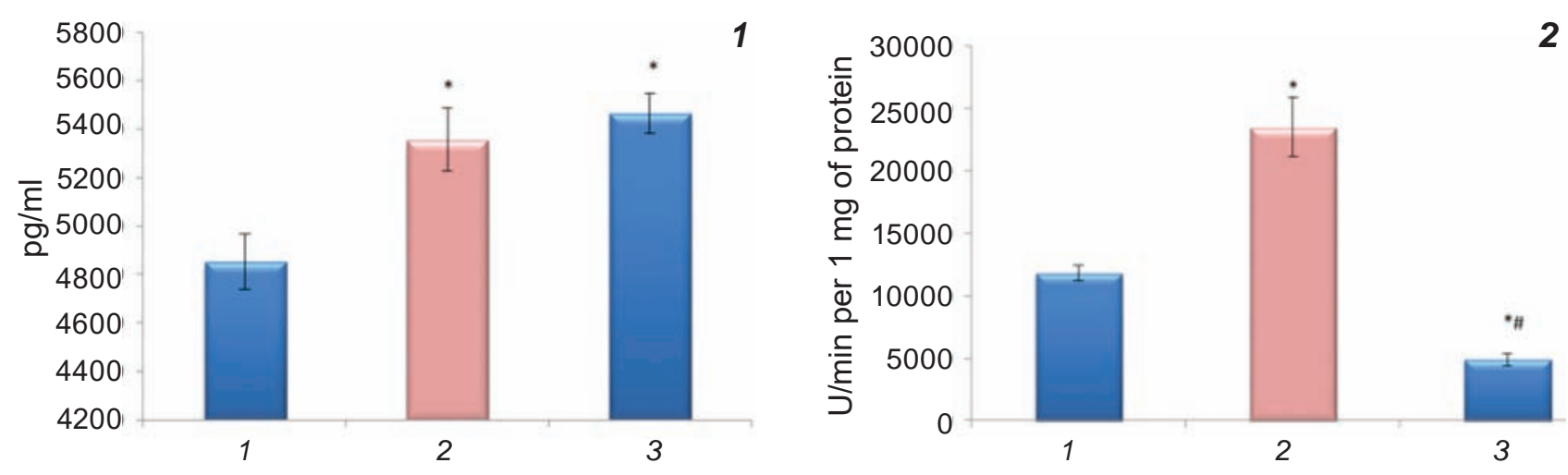

Fig. 3. Superoxide dismutase protein level (1) and activity (2) in frontal cortex of control rats and rats with experimental cognitive impairment: 1 - Control; 2 -Scopolamine; 3 - NSE + Scopolamine; values represent the mean $\pm S E M(n=7) ; * P<0.05$ versus control rats; $\# P<0.05$ versus scopolamine rats 


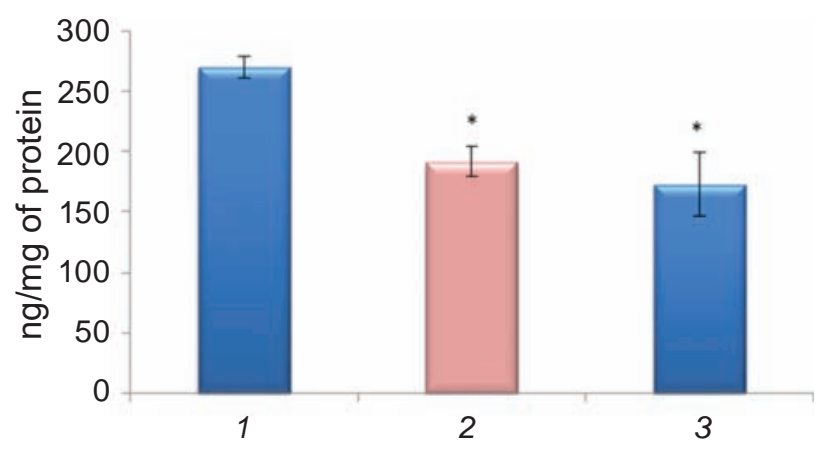

Fig. 4. Frontal cortex nitrotyrosine level in control rats and rats with experimental cognitive impairment: 1 - Control; 2 -Scopolamine; 3 - NSE + Scopolamine; values represent the mean $\pm \operatorname{SEM}(n=7)$; $* P<0.05$ versus control rats; \# $P<0.05$ versus scopolamine rats

NSE prevented the reduction of inorganic phosphorus level of total phospholipids in the hippocampus.

The results of individual phospholipids determination showed that scopolamine administration induced significant changes in the content of main membrane phospholipids - PC, LPC, SM, PS and diphosphatidylglycerol (DPG). Fig. 6 and 7 represent a percentage of each studied individual phospholipid level in the hippocampus and frontal cortex of rats from "Scopolamine" and "NSE+Scopolamine" group.

According to the results from figure 6, scopolamine caused an increase of LPC, SM, PS and decrease of PC and DPG level in rat hippocampus.

The results of current study have shown that NSE administration prevented changes in the level of phosphatidylcholine (PC), lysophosphatidylcholine (LPC), sphingomyelin (SM) and phosphatidylserine (PS) in hippocampus of scopolamine administrated rats, however, NSE did not affect diphosphatidylglycerol (DPG) level (Fig. 6).

The study of phospholipid composition of the frontal cortex indicated that scopolamine administration increased content of SM, DPG and LPC (Fig. 7). Meanwhile, the level of PC was considerably reduced in "Scopolamine" group of rats (Fig. 7). Pretreatment of animals with NSE prevented ob-
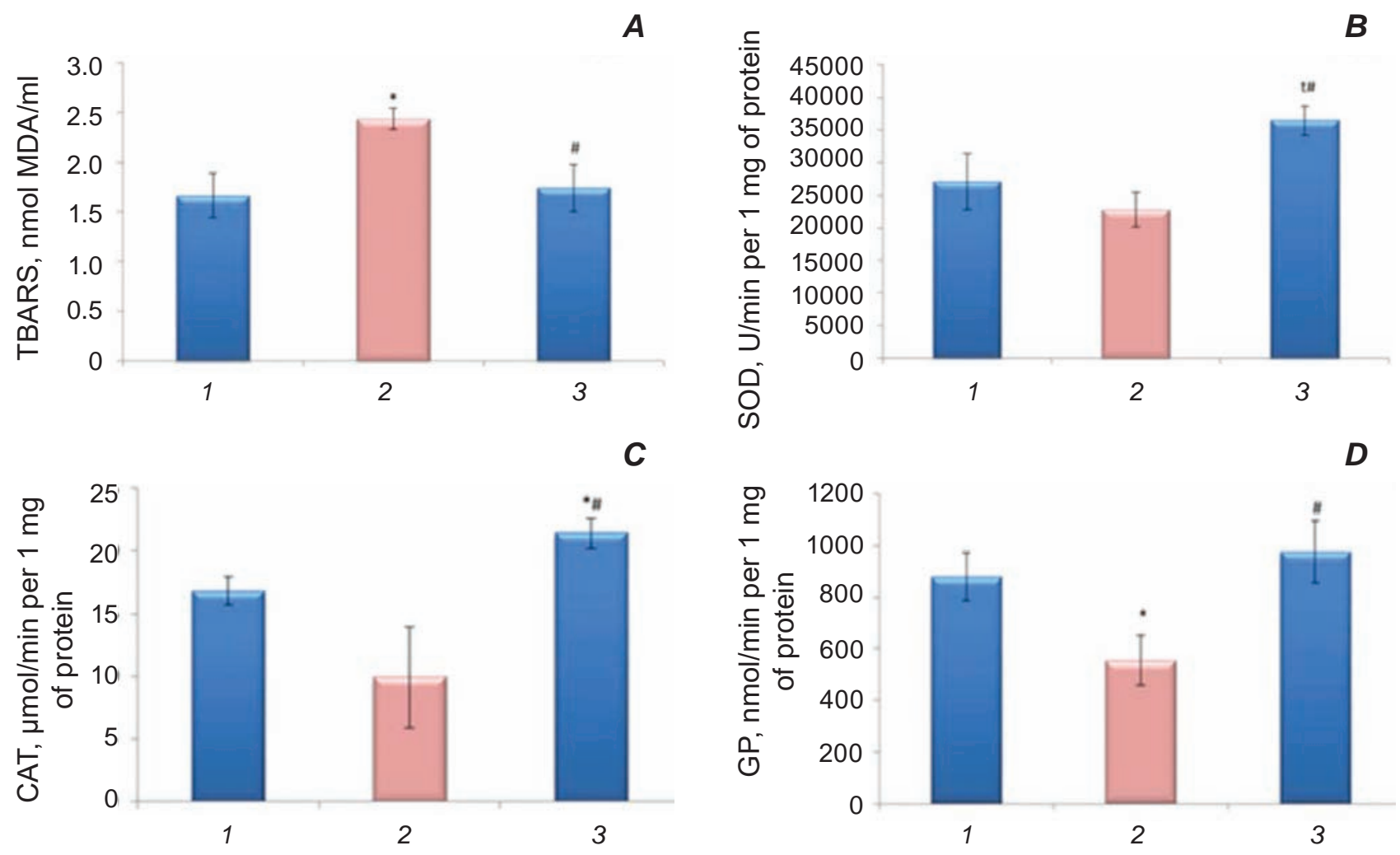

Fig. 5. Plasma thiobarbituric acid reactive substances level (A) and superoxide dismutase (B), catalase (C) and glutathione peroxidase activity (D) in control rats and rats with experimental cognitive impairment: 1 - Control; 2 - Scopolamine; 3 - NSE + Scopolamine; values represent the mean $\pm \operatorname{SEM}(n=7) ; * P<0.05$ versus control rats; $\# P<0.05$ versus scopolamine rats 
Total phospholipid level (mkg $P_{i} / g$ tissue) of frontal cortex and hippocampus in control rats and rats with experimental cognitive impairment $(M \pm m, n=7)$

\begin{tabular}{l|c|c|c}
\hline \multicolumn{1}{c|}{ Tissue } & Intact & Scopolamine & NSE + scopolamine \\
\hline Frontal cortex & $1529.67 \pm 53.62$ & $1591.84 \pm 23.88$ & $1607.72 \pm 24.83$ \\
Hippocampus & $1213.24 \pm 44.39$ & $1092.92 \pm 18.91^{*}$ & $1276.21 \pm 62.55 \#$ \\
\hline
\end{tabular}

Values represent the mean $\pm \operatorname{SEM}(n=7) ;{ }^{*} P<0.05$ versus control rats; ${ }^{\sharp} P<0.05$ versus scopolamine rats.
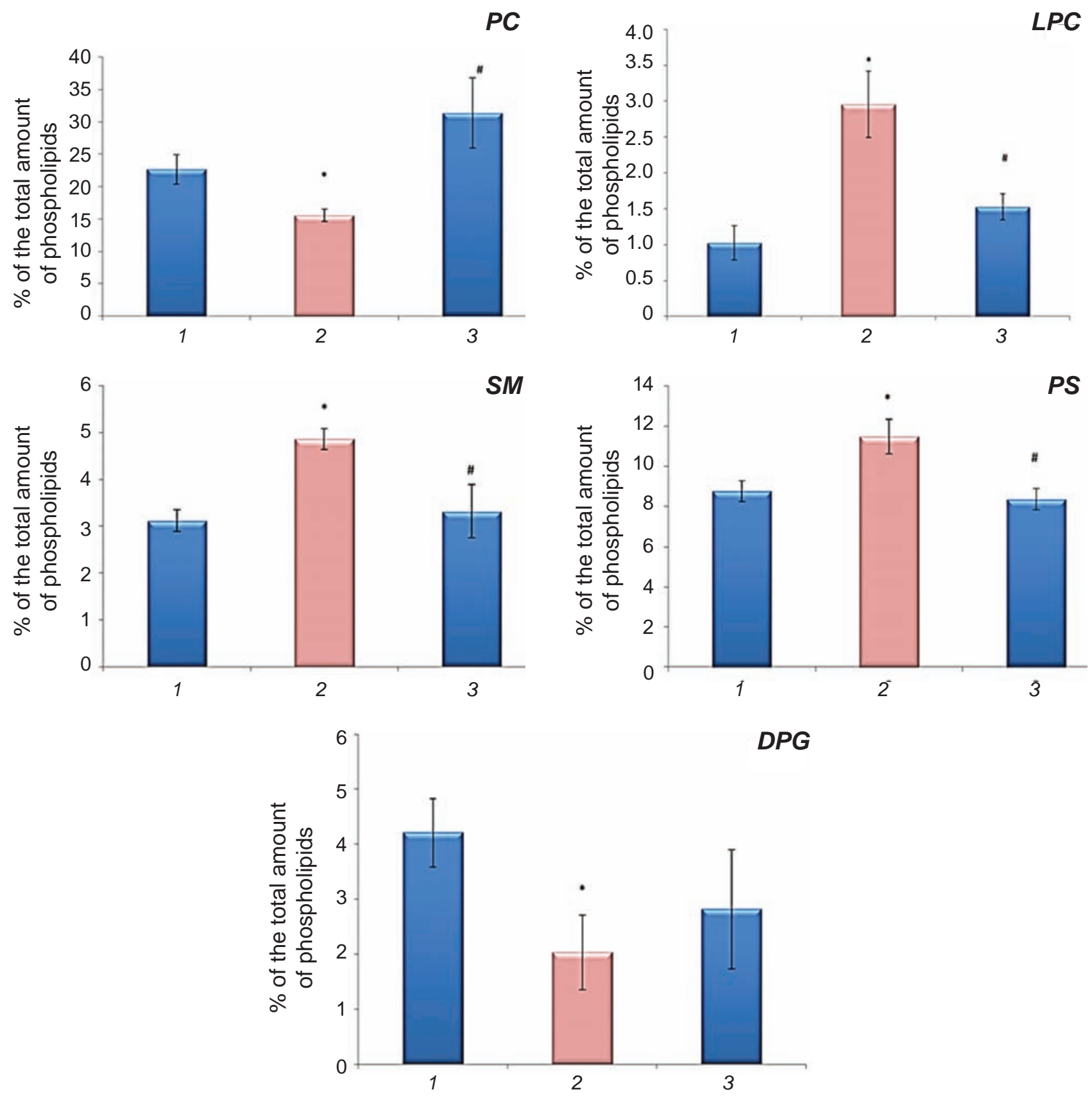

Fig. 6. Hippocampus tissue phospholipid composition (\% of the total amount of phospholipids): PC - phosphatidylcholine; LPC - lysophosphatidylcholine; SM - sphingomyelin; PS - phosphatidylserine; DPG - diphosphatidylglycerol. 1 - Control; 2 -Scopolamine; 3-NSE + Scopolamine; values represent the mean \pm SEM $(n=7) ; * P<0.05$ versus control rats; $\# P<0.05$ versus scopolamine rats 

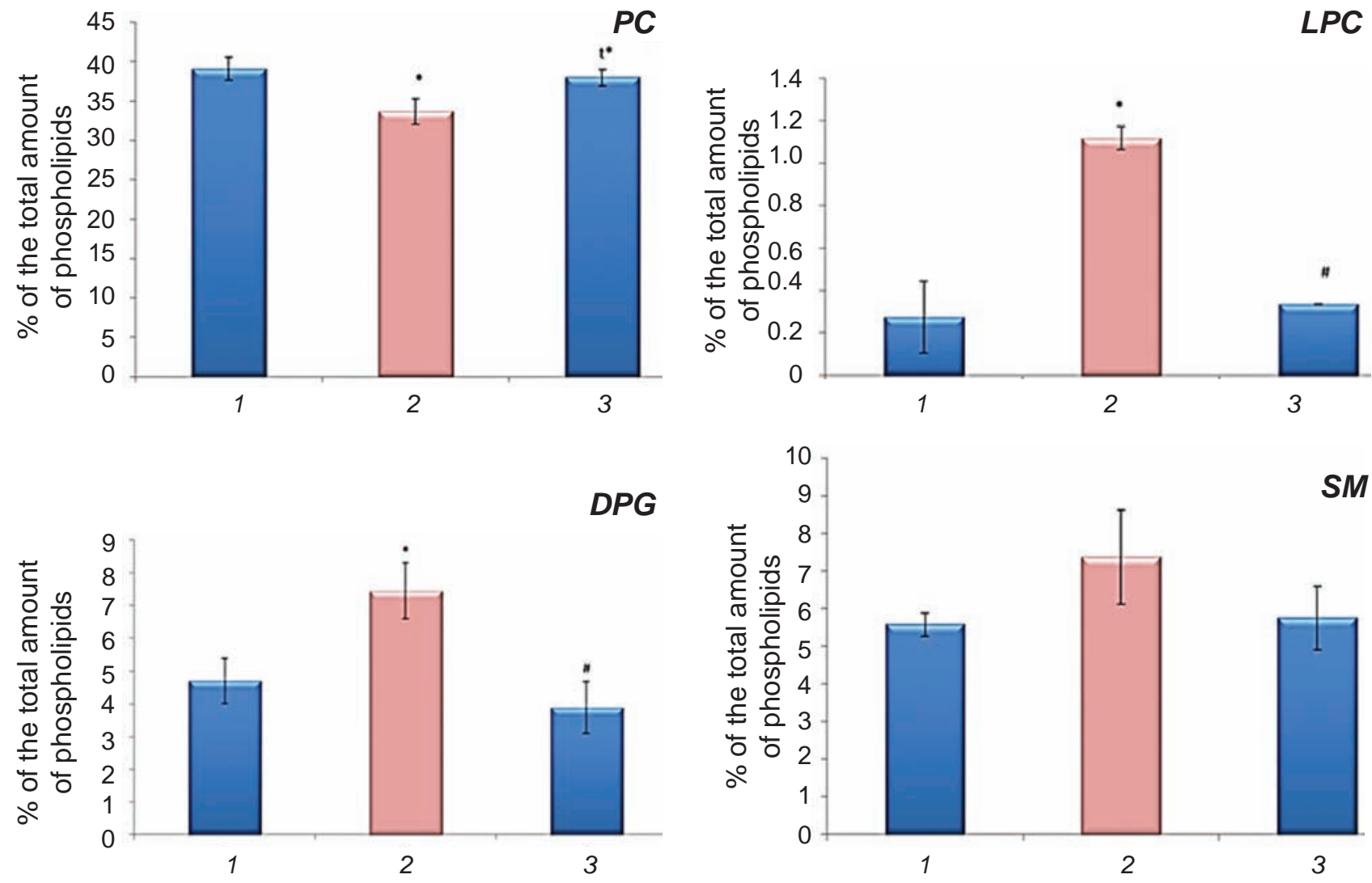

Fig. 7. Frontal cortex tissue phospholipid composition (\% of the total amount of phospholipids): PC - phosphatidylcholine; LPC - lysophosphatidylcholine; SM - sphingomyelin; DPG - diphosphatidylglycerol. 1 -Control; 2 - Scopolamine; 3 - NSE + Scopolamine; values represent the mean $\pm \operatorname{SEM}(n=7) ; * P<0.05$ versus control rats; $\# P<0.05$ versus scopolamine rats

served changes in the phospholipid level of the frontal cortex of rats under scopolamine action.

Cholesterol level in the frontal cortex and hippocampus. Fig. 8 represents the level of free and esterified cholesterol level in different parts of the brain from rats with scopolamine treatment. As shown in Fig. 8, A, 2, scopolamine triggered a significant decrease of free cholesterol level in hippocampus. Pretreatment with NSE prevented changes in free cholesterol level in hippocampus of rats caused by scopolamine administration (Fig. 8, A, 2).

Determination of free cholesterol content in the frontal cortex of rats showed a significant increase of free cholesterol level in rats treated with scopolamine (Fig, 8, A, 1). Pretreatment of rats with NSE did not eliminate the effect of scopolamine on free cholesterol content (Fig. 8, A, 1).

According to our data, presented in Fig, 8, B, scopolamine caused a considerable increase in esterified cholesterol level in rats hippocampus and frontal cortex. Pretreatment with NSE prevented the increase of esterified cholesterol level in the hippocampus, however, no effect in the frontal cortex was found (Fig. 8, B, 2).

This experiment was carried out to evaluate the protective effects of NSE on memory state, blood and brain biochemical parameters in rats under scopolamine-induced cognitive impairment.

It is known that acetylcholine and muscarinic acetylcholine receptors (mAChR) play an important role in learning processes and memory capasity. Previous results showed that M1 mAChR activation by acetylcholine facilitates the induction of synaptic plasticity and enhances cognitive function in rats [19]. On the other hand, behavioral and physiological animal tests showed that the use of muscarinic acetylcholine receptor antagonists (e.g., scopolamine) resulted in decrease of learning and memory ability $[20,21]$. Scopolamine increases the activity of AChE in brain tissue and blood [21-23], leading to a rapid cleavage of acetylcholine, a decrease in its concentration and memory loss. 

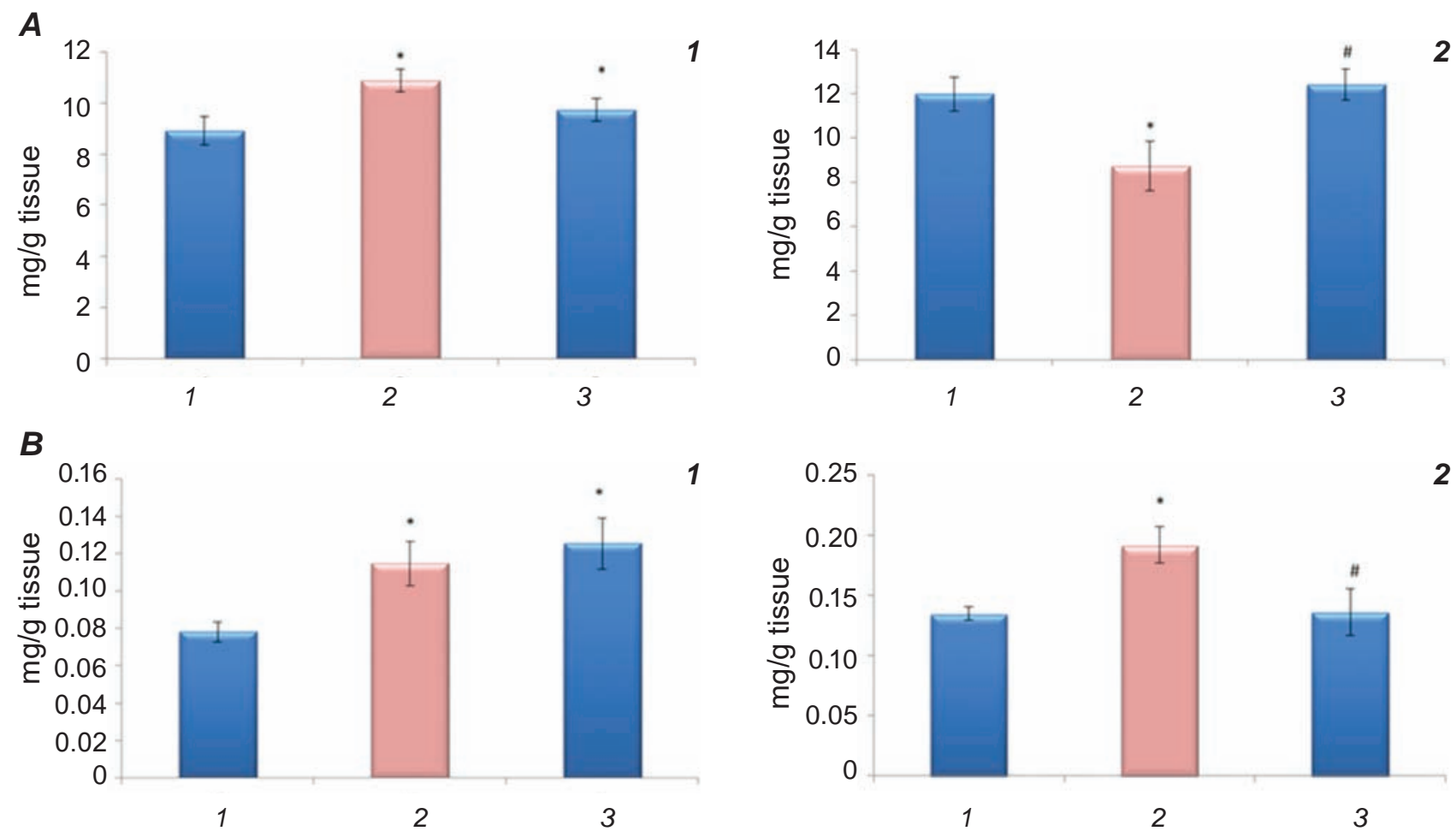

Fig. 8. Frontal cortex (1) and hippocampus (2) tissue free cholesterol (A) and its esterified form (B) content. 1 -Control; 2 -Scopolamine; 3 - NSE + Scopolamine; values represent the mean $\pm \operatorname{SEM}(n=7) ; * P<0.05$ versus control rats; \# $P<0.05$ versus scopolamine rats

Recent studies provide evidence that acetylcholine deficiency is involved in cognitive impairment of both neurodegenerative and vascular origin $[24,25]$.

Thus, cholinergic dysfunctions, such as reduced cholin uptake, increased AChE activity, decreased acetylcholine synthesis, decreased activity and degeneration of cholinergic neurons in certain brain structures, were associated with a decrease of cognitive function in patiens with Alzheimer's disease (AD) [22, 26].

Numerous experimental studies indicated that the activity of AChE is significantly increased in hippocampus, amygdala and cerebral cortex of patients with AD [27].

Notably, AChE inhibitors, such as donepezil, galantamine and rivastigmine, improved cognition and indirectly increased the quality of life in patients with AD [28], however, they were not able to stop the disease progression and showed little therapeutic activity with a few side effects and contraindications.

Recent findings indicated that some of NAEs are competitive (anandamide) and non-competitive (oleoylethanolamine and palmitoylethanolamine) inhibitors of plasma butyrylcholinesterase (BuChE) [29]. Changes in the level and activity of this enzyme were indicated in the pathogenesis of diseases associated with cognitive disorders (AD, multiple sclerosis) [30, 31].

In addition, it has been found that pretreatment of mice with oleoylethanolamine before scopolamine administration prevents the development of cognitive impairment in animals and promotes the growth of choline acetyltransferase activity (ChAT) [32]. At the same time, there are no evidance about NSE effects on AChE, BuChE and ChAT activity.

The results of this study indicated a significant memory loss and increase of AChE activity in plasma of aged rats with experimental cholinergic deficiency induced by scopolamine (Fig. 1, 2). Pretreatment of experimental animals with NSE prevented the growth of acetylcholinesterase activity in plasma and memory impairment in rats under scopolamine action (Fig. 1, 2). Unfortunately, we did not study the NSE action on the plasma ACHE activity of scopolamine - untreated rats.

As previously reported by us NSE caused a protective effect on brain tissue and improved memory 
capacity of mice injected with lipopolysaccharide or immunized with the extracellular domain of $\alpha 7$ nicotinic acetylcholine receptor [6].

Therefore, we can assume that NAEs may prevent the development of cholinergic dysfunction and cognitive impairment in mammals due to downregulation of $\mathrm{AChE}$ and $\mathrm{BuChE}$, and up-regulation of ChAT activity, hence, modulating the level of acetylcholine.

Oxidative stress is suggested to be one of the molecular mechanisms of cholinergic neurodegeneration and cognitive dysfunction in AD [33]. Scopolamine, an antagonist of muscarinic receptors, exhibits a central inhibition of cholinergic transmission, causing oxidative stress development in brain and enhanced memory loss in humans and animals $[22,34]$. Additionally, it has been shown that scopolamine induced down-regulation of neurogenesis, a significant increase of acetylcholinesterase activity and nitric oxide level (enhanced expression of iNOS), accumulation of TBARS (malonic dialdehyde), and a decrease of antioxidant enzymes activity (SOD, CAT, GP) in the hippocampus and cerebral cortex of rats and mice [35]. In addition, scopolamine mediated enhanced formation of reactive oxygen species, a decrease in antioxidants level, an increase of plasma and serum nitric oxide level in animals [35]. Thus, pathogenesis of cholinergic neurodegeneration and development of cognitive impairment induced by scopolamine, is assosiated with oxidative/nitrosative stress, impaired pro-/antioxidant balance in brain tissue and blood samples from humans and animals.

The results of our study showed a significant increase of SOD level and its activity, as well as decrease level of nitrotyrosine in the frontal cortex but not in hippocampus of aged rats with scopolamine - induced cognitive impairment (Fig. 3, 4). Also, obtained data showed a remarcable reduce of SOD, CAT, GP activity and enhanced accumulation of TBARS in plasma of rats under scopolamine administration (Fig. 5).

Pretreatment of experimental animals with NSE prevented the increase of SOD activity but did not prevent the effect of scopolamine on SOD and nitrotirosin level in the frontal cortex (Fig. 3, 4). Also, NSE inhibited formation of TBARS and prevented decrease in SOD, CAT and GP activity in plasma (Fig. 5).

These results agreed with earlier published data where antioxidant enzymes (SOD, CAT and GP) activity was down-regulated in brain tissue during neurodegenerative diseases [33].
It has been known that NAEs, particularly NSE, exhibit adaptogenic, membrane-protective, antioxidant, immunomodulatory, anti-inflammatory, anti-allergic and anti-toxic effects [36]. Additionally, NSE modulated nitric oxide level (by affecting activity of constitutive and inducible NO synthases under different pathological conditions) [37] and reactive oxygen species level (by reducing the production of superoxide anion under LPS treatment) [38]. It worth to mentioning that effect of NSE is observed only under pathological conditions and does not show up under healthy normal conditions [39, 40].

Consequently, NSE prevented scopolamineinduced memory impairment in rats, by changes in pro-/antioxidant balance in brain tissue and blood samples.

It is known that brain is one of the richest tissues in total lipid level, and any changes in brain lipid composition can lead to the development of various pathological processes.

Recently, many studies have indicated disturbances in lipid profile of hippocampus and other brain structures, cerebrospinal fluid and plasma during AD [41-43]. Mainly these changes were assosiated with the basic phospholipids, such as PC, phosphatidylethanolamine (PE), PS, SM, phosphatidylinositol (PI), as well as free fatty acid and phospholipids' fatty acid composition, and cholesterol level [42-45]. It is suggested that phospholipid level in plasma and cerebrospinal fluid may contribute to early detection, risk assessment and therapeutic monitoring of mild cognitive impairment and dementia in AD patients [41].

AD development is correlated with the metabolism of $\beta$-amyloid precursor protein (APP), which is closely related to changes in membrane lipid composition [42]. Secretases and APP are integral proteins, hence their lipid environment can play a significant role in protein metabolism and as a result in beta amyloid $(A \beta)$ generation $[46,47]$.

Therefore, drugs that block muscarinic cholinergic neurotransmission may stimulate $A \beta$ formation and decrease the level of PC in the brain (down-regulating its synthesis and activating its decay). These effects can reduce a number of brain synapses and might cose memory disorders in early stages of AD [48]. Furthermore, agents that inhibit acetylcholinesterase (e.g., rivastigmine) modulated plasma phospholipid profile decreasing choline-containing phospholipids level [49].

It has been found that administration of PC to mice with dementia caused an increase of ace- 
tylcholine level in the brain, following by memory improvement [50]. Other phospholipids administration also showed a positive effect on memory status. Thus, n-3 PI and PS significantly diminished scopolamine-induced amnesia [51].

Consequently, the drug administration may cause preservation or restoration of structural and functional integrity of individual brain structures as well as the whole brain, and should prevent the development of neurodegenerative disorders and loss of cognitive ability.

In conclusion, biologically active compounds $\mathrm{N}$-acetyletanolamines are the promissing drug candidates.

The study of phospholipid content of hippocampus and frontal cortex of rat brain under scopolamine action showed a significant decrease in the content of inorganic phosphorus of total phospholipids in hippocampus, and remarcable changes in the content of main membrane phospholipids (Table, Fig. 6, 7). Pretreatment with NSE prevents changes in total content of phospholipids in the hippocampus and changes in the main individual phospholipids level, such as PC, LPC, SM, PS and DPG in the hippocampus and frontal cortex of aged rats (Table, Fig. 6, 7). The revealed protective effect of NSE on the phospholipid composition of the studied brain structures may mediate its protective effect on memory state (Fig. 1).

Nowadays, it is well known that cholesterol is vital for normal brain function, synaptic plasticity, training and memory [52].

Considering the published data, pathogenesis of numerous cognitive disorders, including AD, Parkinson's disease, Niemann-Pick disease, Huntington's disease, vascular dementia, etc., were correlated with the disturbances of cholesterol metabolism [53-56]. It has been shown that accumulation of cholesterol in hippocampal neurons lead to changes in lipoprotein homeostasis, hippocampal atrophy and cognitive impairment [57]. In addition, the decrease of the cholesterol synthesis in brain was assosiated with memory loss [53]. Moreover, the nicotinic and muscarinic acetylcholine receptors, $\mathrm{Na} / \mathrm{K}$-ATPase, adenylate cyclase, calcium homeostasis, formation and aggregation of $A \beta$ are cholesterol-dependent [58-60].

Based on the results, schopolamine cosed a considerable changes in free and esterified cholesterol level in different parts of aged rat's brain (Fig. 8). Pretreatment with NSE prevented changes in the level of free cholesterol and its esterified form in hippocampus, and level of free cholesterol in frontal cotex of rat brain (Fig. 8).

Thus, NSE is able to modulate the level of free and esterified cholesterol in different parts of rat brain with cholinergic deficiency. We suggest that moderate protective effect of NSE on memory was partly associated with its modulatory action on free and esterified cholesterol level in different brain sections of rats under scopolamine action.

In addition to already known properties of NSE (adaptogenic, neuroprotective and anti-inflammatory properties, inhibition of FAAH-mediated hydrolysis of anandamide and modulation of the permeability of the blood-brain barrier), our results revealed that NSE also prevented a memory loss and an increase of acetylcholinesterase activity, imbalance of antioxidant system in plasma, hippocampus and frontal cortex of rats, changes in phospholipid composition, free cholesterol and esterified cholesterol level in studied brain structures. Taking into account that NSE is a member of endocannabinoid system, the obtained data also provided a clear understanding of the endocannabinoids protective role under the cognitive impairment. Therefore, the results of this study can form the basis for considering NSE as a promising tool in drug development for prevention and treatment of cognitive impairment of different profiles.

\section{ПРЕВЕНТИВНА ДІЯ \\ N-СТЕАРОЇЛЕТАНОЛАМІНУ \\ НА РОЗВИТОК ПОРУШЕННЯ \\ ПАМ'ЯТІ, БІОХІМІЧНІ ПАРАМЕТРИ \\ КРОВІ ТА МОЗКУ В ЩУРІВ 3 \\ ЕКСПЕРИМЕНТАЛЬНИМИ \\ СКОПОЛАМІНІНДУ КОВАНИМИ КОГНІТИВНИМИ ПОРУШЕННЯМИ}

\author{
T. М. Горідько ${ }^{1}$, Г. В. Косякова ${ }^{1}$, \\ А. Г. Бердишев ${ }^{1}$, О. Ф. Мегедь ${ }^{1}$, \\ О. В. Онопченко ${ }^{1}$, В. М. Клімашевський ${ }^{1}$, \\ О. С. Ткаченко ${ }^{1}$ В. Р. Базилянська ${ }^{1}$, \\ В. О. Холін ${ }^{2}$, К. О. Песчана ${ }^{2}$, \\ С. А. Михальськийㄹ, Н. М. Гула \\ ${ }^{1}$ Інститут біохімії ім. О. В. Палладіна \\ НАН України, Київ; \\ ${ }^{2}$ Інститут геронтології НАМН України, Київ; \\ e-mail: TanGoRi@ukr.net
}

Порушення когнітивних функцій $є$ найактуальнішою медичною та соціальною проблемою сьогодення. Метою роботи було оціни- 
ти протекторний вплив N-стеароїлетаноламіну (NSE) на стан пам'яті, біохімічні показники крові та головного мозку в щурів за індукованих скополаміном когнітивних розладів. Результати досліджень показали, що NSE за умов введення його щурам per os (5 мг/кг, 5 днів, протягом останніх 3 днів за 20 хв до введення скополаміну (1 мг/кг, один раз на добу протягом 3 днів, інтраперитонеально)) запобігає розвитку порушення пам'яті. Виявлений ефект NSE може бути обумовлений його здатністю запобігати зростанню ацетилхолінестеразної активності, порушенню про/антиоксидантної рівноваги в плазмі крові, гіпокампі та фронтальній корі головного мозку тварин, змінам вмісту фосфоліпідів, вільного холестеролу та його ефірів у досліджуваних відділах головного мозку щурів. Виявлені біологічні ефекти N-стеароїлетаноламіну свідчать, що NSE $€$ перспективною сполукою для створення на його основі нового лікарського засобу для лікування когнітивних порушень різного генезу.

К л ю ч о в і с л о в а: N-стеароїлетаноламін, фосфоліпіди, холестерол, супероксиддизмутаза, каталаза, глутатіонпероксидаза, нітротирозин, ТБК-активні продукти, ацетилхолінестераза, скополамін.

\section{ПРЕВЕНТИВНОЕ ДЕЙСТВИЕ N-СТЕАРОИЛЭТАНОЛАМИНА НА РАЗВИТИЕ НАРУШЕНИЯ ПАМЯТИ, БИОХИМИЧЕСКИЕ ПАРАМЕТРЫ КРОВИ И МОЗГА КРЫС С ЭКСПЕРИМЕН- ТАЛЬНЫМИ СКОПОЛАМИН- ИНДУЦИРОВАННЫМИ КОГНИТИВНЫМИ НАРУШЕНИЯМИ}
T. Н. Горидько, Г. В. Косякова
А. Г. Бердыпеев ${ }^{1}$, Е. Ф. Мегедь ${ }^{1}$, А. В. Онопченко ${ }^{1}$ В. М. Климатевский ${ }^{1}$,
О. С. Ткаченко ${ }^{1}$ В. Р. Базилянская ${ }^{1}$, В. А. Холин ${ }^{2}$ Е. О. Песчаная ${ }^{2}$, С. А. Михальский ${ }^{2}$ Н. М. Гулая ${ }^{1}$

${ }^{1}$ Институт биохимии им. А. В. Палладина НАН Украины, Киев;

${ }^{2}$ Институт геронтологии НАМН Украины, Киев; e-mail: TanGoRi@ukr.net

$\begin{array}{ccc}\text { Нарушение когнитивных } & \text { функ- } \\ \text { ций является наиболее актуальной } & \text { меди- }\end{array}$

цинской и социальной проблемой современности. Целью работы было оценить протекторное влияние $\mathrm{N}$-стеароилэтаноламина (NSE) на состояние памяти, биохимические показатели крови и головного мозга крыс при скополамининдуцированных когнитивных нарушениях. Результаты исследований показали, что NSE при введении крысам per os (5 мг/кг, 5 дней, последние 3 дня за 20 минут до введения скополамина (1 мг/кг один раз в сутки в течение 3 дней, интраперитонеально)) предупреждает развитие нарушения памяти. Обнаруженный эффект NSE может быть обусловлен его способностью препятствовать увеличению ацетилхолинестеразной активности, нарушению про/ антиоксидантного равновесия в плазме крови, гиппокампе и фронтальной коре головного мозга животных, изменением содержания фосфолипидов, свободного холестерина и его эфиров в исследуемых отделах головного мозга крыс. Выявленные биологические эффекты $\mathrm{N}$-стеароилэтаноламина свидетельствуют, что NSE является перспективным соединением для создания на его основе нового лекарственного средства для лечения когнитивных нарушений различного генеза.

Ключевы е слов а: $\quad \mathrm{N}$-стеароилэтаноламин, фосфолипиды, холестерин, супероксиддизмутаза, каталаза, глутатионпероксидаза, нитротирозин, ТБК-активные продукты, ацетилхолинэстераза, скополамин.

\section{References}

1. Zanettini C, Panlilio LV, Alicki M, Goldberg SR, Haller J, Yasar S. Effects of endocannabinoid system modulation on cognitive and emotional behavior. Front Behav Neurosci. 2011; 5: 57.

2. Hind WH, Tufarelli C, Neophytou M, Anderson SI, England TJ, O'Sullivan SE. Endocannabinoids modulate human blood-brain barrier permeability in vitro. $\mathrm{Br} J$ Pharmacol. 2015; 172(12): 3015-3027.

3. Panlilio LV, Justinova Z, Goldberg SR. Inhibition of FAAH and activation of PPAR: new approaches to the treatment of cognitive dysfunction and drug addiction. Pharmacol Ther. 2013; 138(1): 84-102.

4. Costa B, Comelli F, Bettoni I, Colleoni M, Giagnoni G. The endogenous fatty acid amide, palmitoylethanolamide, has anti-allodynic and anti-hyperalgesic effects in a murine model of 
neuropathic pain: involvement of CB(1), TRPV1 and PPARgamma receptors and neurotrophic factors. Pain. 2008; 139(3): 541-550.

5. Moreno S, Cerù MP. In search for novel strategies towards neuroprotection and neuroregeneration: is PPAR $\alpha$ a promising therapeutic target? Neural Regen Res. 2015; 10(9): 1409-1412.

6. Lykhmus O, Uspenska K, Koval L, Lytovchenko D, Voytenko L, Horid'ko T, Kosiakova H, Gula N, Komisarenko S, Skok M. N-Stearoylethanolamine protects the brain and improves memory of mice treated with lipopolysaccharide or immunized with the extracellular domain of $\alpha 7$ nicotinic acetylcholine receptor. Int Immunopharmacol. 2017; 52: 290-296.

7. Maccarrone M, Cartoni A, Parolaro D, Margonelli A, Massi P, Bari M, Battista N, Finazzi-Agrò A. Cannabimimetic activity, binding, and degradation of stearoylethanolamide within the mouse central nervous system. $\mathrm{Mol}$ Cell Neurosci. 2002; 21(1): 126-140.

8. Klinkenberg I, Blokland A. A comparison of scopolamine and biperiden as a rodent model for cholinergic cognitive impairment. Psychopharmacology (Berl). 2011; 215(3): 549566.

9. Ding Q, Sethna F, Wang H. Behavioral analysis of male and female Fmr1 knockout mice on C57BL/6 background. Behav Brain Res. 2014; 271: 72-78.

10. A guide to preclinical drug research. Ed. A. N. Mironov. Moscow: FGBU "NTSESMP", 2012. 944 p. (In Russian).

11. Bligh EG, Dyer WJ. A rapid method of total lipid extraction and purification. Can J Biochem Physiol. 1959; 37(8): 911-917.

12. Svetashev VI, Vaskovsky VE. A simplified technique for thin-layer microchromatography of lipids. J Chromatogr. 1972; 67(2): 376-378.

13. Vaskovsky VE, Kostetsky EY, Vasendin IM. A universal reagent for phospholipid analysis. J Chromatogr. 1975; 114(1): 129-141.

14. Mel'nychuk SD, Kuz'menko AI, Margitich VM, Govseeva NN, Gorid'ko TN, Hulaia NM. Effect of carbon dioxide on free radical processes as affected by artificial hypobiosis in rats. $U k r$ Biokhim Zhurn. 1998; 70(1): 87-94. (In Russian).

15. Csóvári S, Andyal T, Strenger J. Determination of the antioxidant properties of the blood and their diagnostic significance in the elderly. Lab Delo. 1991; (10): 9-13. (In Russian).
16. Koroliuk MA, Ivanova LI, Mayorova IG, Tokarev VE. A method of determining catalase activity. Lab Delo. 1988; (1): 16-19. (In Russian).

17. Pereslegina IA. The activity of antioxidant enzymes in the saliva of normal children. $L a b$ Delo. 1989; (11): 20-23. (In Russian).

18. Bradford MM. A rapid and sensitive method for the quantitation of microgram quantities of protein utilizing the principle of protein-dye binding. Anal Biochem. 1976; 72: 248-254.

19. Buchanan KA, Petrovic MM, Chamberlain SE, Marrion NV, Mellor JR. Facilitation of long-term potentiation by muscarinic $\mathrm{M}(1)$ receptors is mediated by inhibition of SK channels. Neuron. 2010; 68(5): 948-963.

20. Soares JC, Oliveira MG, Ferreira TL. Inactivation of muscarinic receptors impairs place and response learning: implications for multiple memory systems. Neuropharmacology. 2013; 73: 320-326.

21. Bihaqi SW, Singh AP, Tiwari M. In vivo investigation of the neuroprotective property of Convolvulus pluricaulis in scopolamine-induced cognitive impairments in Wistar rats. Indian $J$ Pharmacol. 2011; 43(5): 520-525.

22. Sridharamurthy NB, Ashok B, Yogananda R. Evaluation of antioxidant and acetyl cholinesterase inhibitory activity of Peltophorum pterocarpum in scopolamine treated rats. Int $J$ Drug Dev Res. 2012; 4(3): 115-127.

23. Sahraei E, Soodi M, Jafarzadeh E, Karimivaghef $Z$. Investigation of the scopolamine effect on acetylcholinesterase activity. Res Pharm Sci. 2012; 7(5): S152.

24. Wang J, Zhang HY, Tang XC. Cholinergic deficiency involved in vascular dementia: possible mechanism and strategy of treatment. Acta Pharmacol Sin. 2009; 30(7): 879-888.

25. Tata AM, Velluto L, D'Angelo C, Reale M. Cholinergic system dysfunction and neurodegenerative diseases: cause or effect? CNS Neurol Disord Drug Targets. 2014; 13(7): 12941303.

26. Fields RD, Dutta DJ, Belgrad J, Robnett M. Cholinergic signaling in myelination. Glia. 2017; 65(5): 687-698.

27. Serrano-Pozo A, Frosch MP, Masliah E, Hyman BT. Neuropathological alterations in Alzheimer disease. Cold Spring Harb Perspect Med. 2011; 1(1): a006189.

28. Meguro K, Kasai M, Akanuma K, Meguro M, Ishii H, Yamaguchi S. Donepezil and 
life expectancy in Alzheimer's disease: a retrospective analysis in the Tajiri Project. BMC Neurol. 2014; 14: 83.

29. Romani R, Galeazzi R, Rosi G, Fiorini R, Pirisinu I, Ambrosini A, Zolese G. Anandamide and its congeners inhibit human plasma butyrylcholinesterase. Possible new roles for these endocannabinoids? Biochimie. 2011; 93(9): 1584-1591.

30. Darvesh S, Leblanc AM, Macdonald IR, Reid GA, Bhan V, Macaulay RJ, Fisk JD. Butyrylcholinesterase activity in multiple sclerosis neuropathology. Chem Biol Interact. 2010; 187(1-3): 425-431.

31. DeBay DR, Reid GA, Pottie IR, Martin E, Bowen CV, Darvesh S. Targeting butyrylcholinesterase for preclinical single photon emission computed tomography (SPECT) imaging of Alzheimer's disease. Alzheimers Dement (N Y). 2017; 3(2): 166-176.

32. Heo HJ, Park YJ, Suh YM, Choi SJ, Kim MJ, Cho HY, Chang YJ, Hong B, Kim HK, Kim E, Kim CJ, Kim BG, Shin DH. Effects of oleamide on choline acetyltransferase and cognitive activities. Biosci Biotechnol Biochem. 2003; 67(6): 1284-1291.

33. Fisher A., Hanin I., Mizuno Y. Mapping the progress of Alzheimer's and Parkinson's Disease. New York : Kluwer Academic. Plenum Publishers, 2002. 566 p.

34. Pattanashetti LA, Taranalli AD, Parvatrao V, Malabade RH, Kumar D. Evaluation of neuroprotective effect of quercetin with donepezil in scopolamine-induced amnesia in rats. Indian J Pharmacol. 2017; 49(1): 60-64.

35. Lee JS, Kim HG, Lee HW, Han JM, Lee SK, Kim DW, Saravanakumar A, Son CG. Hippocampal memory enhancing activity of pine needle extract against scopolamine-induced amnesia in a mouse model. Sci Rep. 2015; 5: 9651.

36. Zhukov AD, Berdyshev AG, Kosiakova GV, Klimashevskiy VM, Gorid'ko TM, Meged OF, Hula NM. N-stearoylethanolamine effect on the level of 11-hydroxycorticosteroids, cytokines IL1, IL-6 and TNFalpha in rats with nonspecific inflammation caused by thermal burn of skin. Ukr Biochem J. 2014; 86(3): 88-97. (In Ukrainian).

37. Kosiakova HV, Hula NM. The N-stearoylethanolamine effect on the NO-synthase way of nitrogen oxide formation and phospholipid composition of erythrocyte membranes in rats with streptozotocine diabetes. Ukr Biokhim Zhurn. 2007; 79(6): 53-59. (In Ukrainian).

38. Berdyshev AG, Kosiakova HV, Hula NM. Modulation of LPS-induced ROS production and NF- $\kappa \mathrm{B}$ nuclear translocation by $\mathrm{N}$-stearoylethanolamine in macrophages. $\mathrm{Ukr}$ Biochem J. 2017; 89(5): 62-69.

39. Goridko TM, Kosiakova GV, Berdyschev AG, Bazylyanska VR, Margitich VM, Gula NM. The influence of N-stearoylethanolamine on the activity of antioxidant enzymes and on the level of stable NO metabolites in the rat testes and blood plasma at the early stages of streptozotocine-induced diabetes. Ukr Biokhim Zhurn. 2012; 84(3): 37-43.

40. Onopchenko OV, Kosiakova GV, Meged EF, Klimashevsky VM, Hula NM. The effect of $\mathrm{N}$-stearoylethanolamine on cholesterol content, fatty acid composition and protein carbonylation level in rats with alimentary obesity-induced insulin resistance. Ukr Biochem J. 2014; 86(6): 119-128.

41. Li D, Misialek JR, Boerwinkle E, Gottesman RF, Sharrett AR, Mosley TH, Coresh J, Wruck LM, Knopman DS, Alonso A. Plasma phospholipids and prevalence of mild cognitive impairment and/or dementia in the ARIC Neurocognitive Study (ARIC-NCS). Alzheimers Dement (Amst). 2016; 3: 73-82.

42. Kosicek M, Hecimovic S. Phospholipids and Alzheimer's disease: alterations, mechanisms and potential biomarkers. Int J Mol Sci. 2013; 14(1): $1310-1322$.

43. Chan RB, Oliveira TG, Cortes EP, Honig LS, Duff KE, Small SA, Wenk MR, Shui G, Di Paolo G. Comparative lipidomic analysis of mouse and human brain with Alzheimer disease. J Biol Chem. 2012; 287(4): 2678-2688.

44. Kim M, Nevado-Holgado A, Whiley L, Snowden SG, Soininen H, Kloszewska I, Mecocci P, Tsolaki M, Vellas B, Thambisetty M, Dobson RJB, Powell JF, Lupton MK, Simmons A, Velayudhan L, Lovestone S, Proitsi P, Legido-Quigley C. Association between Plasma Ceramides and Phosphatidylcholines and Hippocampal Brain Volume in Late Onset Alzheimer's Disease. J Alzheimers Dis. 2017; 60(3): 809-817.

45. Proitsi P, Kim M, Whiley L, Simmons A, Sattlecker M, Velayudhan L, Lupton MK, 
Soininen H, Kloszewska I, Mecocci P, Tsolaki M, Vellas B, Lovestone S, Powell JF, Dobson RJ, Legido-Quigley C. Association of blood lipids with Alzheimer's disease: A comprehensive lipidomics analysis. Alzheimers Dement. 2017; 13(2): 140-151.

46. Fabelo N, Martín V, Marín R, Moreno D, Ferrer I, Díaz M. Altered lipid composition in cortical lipid rafts occurs at early stages of sporadic Alzheimer's disease and facilitates APP/BACE1 interactions. Neurobiol Aging. 2014; 35(8): 18011812.

47. Yang X, Sun GY, Eckert GP, Lee JC. Cellular membrane fluidity in amyloid precursor protein processing. Mol Neurobiol. 2014; 50(1): 119-129.

48. Wurtman RJ. How Anticholinergic Drugs Might Promote Alzheimer's Disease: More Amyloid- $\beta$ and Less Phosphatidylcholine. J Alzheimers Dis. 2015; 46(4): 983-987.

49. Alesenko AV. The potential role for sphingolipids in neuropathogenesis of Alzheimer's disease. Biomed Khim. 2013; 59(1): 25-50. (In Russian).

50. Chung SY, Moriyama T, Uezu E, Uezu K, Hirata R, Yohena N, Masuda Y, Kokubu T, Yamamoto S. Administration of phosphatidylcholine increases brain acetylcholine concentration and improves memory in mice with dementia. J Nutr. 1995; 125(6): 1484-1489.

51. Vaisman N, Pelled D. n-3 phosphatidylserine attenuated scopolamine-induced amnesia in middle-aged rats. Prog Neuropsychopharmacol Biol Psychiatry. 2009; 33(6): 952-959.

52. Schreurs BG. The effects of cholesterol on learning and memory. Neurosci Biobehav Rev. 2010; 34(8): 1366-1379.
53. Zhang J, Liu Q. Cholesterol metabolism and homeostasis in the brain. Protein Cell. 2015; 6(4): 254-264.

54. Petrov AM, Kasimov MR, Zefirov AL. Brain cholesterol metabolism and its defects: linkage to neurodegenerative diseases and synaptic dysfunction. Acta Naturae. 2016; 8(1): 58-73.

55. Paul R, Choudhury A, Kumar S, Giri A, Sandhir R, Borah A. Cholesterol contributes to dopamine-neuronal loss in MPTP mouse model of Parkinson's disease: Involvement of mitochondrial dysfunctions and oxidative stress. PLoS One. 2017; 12(2): e0171285.

56. Appleton JP, Scutt P, Sprigg N, Bath PM. Hypercholesterolaemia and vascular dementia. Clin Sci (Lond). 2017; 131(14): 1561-1578.

57. Ayciriex S, Djelti F, Alves S, Regazzetti A, Gaudin M, Varin J, Langui D, Bièche I, Hudry E, Dargère D, Aubourg P, Auzeil N, Laprévote O, Cartier N. Neuronal Cholesterol Accumulation Induced by Cyp46a1 Down-Regulation in Mouse Hippocampus Disrupts Brain Lipid Homeostasis. Front Mol Neurosci. 2017; 10: 211.

58. Borroni V, Barrantes FJ. Cholesterol modulates the rate and mechanism of acetylcholine receptor internalization. J Biol Chem. 2011; 286(19): 17122-17132.

59. Grouleff J, Irudayam SJ, Skeby KK, Schiøtt B. The influence of cholesterol on membrane protein structure, function, and dynamics studied by molecular dynamics simulations. Biochim Biophys Acta. 2015; 1848(9): 1783-1795.

60. Sun JH, Yu JT, Tan L. The role of cholesterol metabolism in Alzheimer's disease. $\mathrm{Mol}$ Neurobiol. 2015; 51(3): 947-965.

Received 27.06.2018 